\title{
On the True Economies of England's Naval Power
}

\section{Captain J. H. Selwyn R.N.}

To cite this article: Captain J. H. Selwyn R.N. (1871) On the True Economies of England's Naval Power, Royal United Services Institution. Journal, 15:63, 157-175, DOI: 10.1080/03071847109417041

To link to this article: http://dx.doi.org/10.1080/03071847109417041

\section{曲 Published online: 11 Sep 2009.}

Submit your article to this journal $\pi$

Џll Article views: 3

Q View related articles $\longleftarrow$ 


\title{
Ëbriming dillectiung.
}

\author{
Monday, Febiunry 20tb, 1871. \\ Admiral of the Fleet SIR GEORGI lROSE SAl'TORIUS, K.C.B., \\ in the Chair.
}

NAMLES OF MEKBERS who joined the Institution between the 14th and 20th of February, $18 i 1$.

ATNUIL.

Trerelyuu, II. W., ML.Gencral R.A. Macneil, J. G. R. D., Licut. 4lst Ifad. I'user, E. Bourcrie, Comr. R.x. Dat. Infoutry

\section{ON THE.TRUE ECONOMHES OF ENGLAND'S NAVAL POWER.}

\author{
By Gapiain J. II. SeLwm; R.A.
}

Is the year that has just passed away, there has been suffered by the Navy of England a grent and extraordinary loss. A lesson of unprecedented severity has been taught to all who are connected with England's Naval power. That loss and that lesson should now produco their legitimate and ouly useful effects, and this will not bo tho case, should vain regrets over the past, or still more vain recriminations in the present, bo allowed to talse the place of due precautions for the future, or of calm scientific enquiry into the occult cnuses of disaster. My purpose, therefore; in this paper will be to consider the false economies that haro led, or that may still lead, to such eril results, and the true economies that may almost certainly prevent them. In doing this, I shall not confine myself to the consideration alone of such failures as that of the "Captain," but I shall attenpt to notice some of the most obvious changes that may be and ought to be made, in order still further to develop and secure that important basis of the greatness of this country, which is found in her Naval power.

I shall commence by observing; that of all unwise economies, that has erer been held to be the most foolish, which to secure a slightly or 
eren considerably lessened cost in the first instance, sacrifices the real efficiency of the thing constructed. Such a case arises when we construct any new type of ressel on the large scale, without exhaustive previous experiment on the small scale. Such a case arises when for the sake of a lessened cost of ship, we reduce the number of day's fuel at full steaming pouce carried by a man-of-war. Such a case arises again when, to reduce estimates for coal, we prevent the acquirement of that knowledge by the officers who have to use those men-of-war which can alone obtain a successful result, when their right use has become a vital necessity. Such a case always arises when, to satisfy a popular clamour, we cut down votes for the purposes of experiment; we discourage and attempt to rob inventors; whenever, in short, we persist in doing things the wrong way instead of bending all our energies to the discovery of the right mode of action, simply because it is less troublesome to follow beaten paths even at the cost of going astray from our real object, than to understand those who press on our attention a new road to success. If, instead of issuing an order to abstain on all but special occasions from the use of steam, an offer were made of a reward for, or cren interest were shown in, the proper utilization of fuel, science would not hare to regret the fact, that in our Navy only half the true evaporative power-only half the mechanical duty of which even our present fuel is capable, is ever ordinarily obtained in practice-and our Officers would attain a knowledge of steam tactics with no greater expense than at present. I draw attention particularly to the latter fact, for a fact it is. Numerous British merchant steamers have been running for years, and one corrette in the British Navy has been running for months, developing just twice the mechanical power, with the same consumption of fuel. H.M.S. "Briton" has been able, by the adoption, in a moderate degree, of tho improvement of which I speak, and which has been known and practised by the mercantile marine for some time, to burn less than $2 \mathrm{lbs}$. of coal per indicated horse-power instead of 4 and $4 \frac{1}{2}$, which is the consumption of other, even recently built, ressels of our Navy. In other words, if we take the caso of a ressel of 800 nominal horsepower, which would ordinarily burn 75 tons a-day at full steaming, the same power is now obtained by one, and ought long ago to have been obtained by every ship in the Navy by the expenditure of 35 tons only. The improrement I refer to, is, that known as the compound engine, but which really depends solely on the use of a higher pressure in the boiler, for its satisfactory results. When steam pressure in the boiler is as high as $80 \mathrm{lbs}$. instead of $25 \mathrm{lb}$. or $30 \mathrm{lb}$., as we are now using, there is this great difference: at the pressuro of $s 0 \mathrm{lb}$., the temperature is $324^{\circ} \mathrm{F}$., inistend of with $25 \mathrm{lbs}$. or $30 \mathrm{lbs}$. respectively, $267^{\circ} \mathrm{F}$. or $274^{\circ} \mathrm{F}$. This difference in the latent hent enables us to use the steam twice over, first in a high-pressure cjlinder where there is no attempt at condensation or the production of a vacuum; and, secondly, in the ordinary condensing cylinder in which such means of producing a greater effect have always been used. But there is an invention in progress to which my notice has recently been drawn, and which I believe likely to succeed admirably well, which will relieve us from the 
necessity of having any boiler at all, though we must still have a furnace and fuel. As matters are at present, $I$ should in rain solicit any due attention to this fact, and this'ought not so to be. I have said that according to actual facts patent to everyone, our ships that now are being built, or that hare been built for the past two years, ought to be running on just half the iuel they at present use or coutemplate the use of. I now propose to show you that I have myself proved more than a year ago that they might bo run with one half of that again, so that the expenditure above referred to of 75 tons per day for 800 nominal horse-power would be reduced by the first improrement in one of the " true economies" to 35 tons per day, and by the second to $\mathbf{1 7 \cdot 5}$ tons per day. In other words, if at present such a porrer could be exerted for three days, the the first improrement would make it six days, and the second 12 days. On the table of experiments with liquid fuel which I show (see Appendix) you will see that each pound of fuel was made to evaporate $17 \mathrm{lbs}$. of water instead of eight, which could be done with other fuel (solid) in the same boiler, and that considerably more water was evaporated in the same time and with the samo heating surface, and this with an ordinary boiler, perfectly capable of burning coal, as usual, if required, and having added to it no expensive or cumbrous apparatus. Therefore, wise and cautious experiment, steadily continued, might long ago hare giren us this, which 1 put forward as one great and true economy of our naval power.

The next part of my subject will be the consideration of wind-porrer, which there is a strong tendency to ignore, or to undervalue by those who, being only engineers, prefer to rely entircly on fuel for their motive power.

And here I will remark that it is absolutely certain that wind-power can be efficiently utilised even where sufficiently powerful cońsiderations exist to prevent the use of ordinary masts and sails. I have seen models propelled in the wind's eye by wind power, strango as the assertion may seem to those who do not consider that the propeller may be acting under different laws, and be in a different condition from that which they suppose two miles per hour dead to windward is more than most vessels with full sail power can accomplish by beating, and this could easily be done by the application of a fraction of the wind power to a propeller acting on the water, or to a self-contained power like the turbine or hydraulic propeller. I say self-contained, for the hydraulic propeller differs in this from all other modes of propulsion, that it has no other limit than the horse-power of the engine that drives it, to the speed attainable by its use. The paddle, or the screw, after attaining a certain velocity, will churn the water, but will fail to drive the ship; tho hydraulic propeller will giro useful effect in increased speed for every lb. of fuel you can burn, for every additional horse-power that you can generate.

So far as I know this fact has nerer even been noticed hitherto by the inventors or adrocates of the "Waterwitch," and it ought to be strictly investigated.

But to return to wind-power, however applied, there is first the great 
economy during peace to be considered that results from its use, there is, secondly, tho fact that engines may break down, that boilers may burst, that your coaling port or fnel clepôt may bo blockaded just when you have used the last few tons in reaching it, and, lastly; that it has not yet been shown, either at Lissn, or anywhere else, that the masts of vessels were really a cause of serions impediment either under stean or in action, while it is indubitable that in many cases tho irregular morements of a ressel aro beneficially modified by the presence of masts and sails, and most injuriously affected by their nbsence. $\Lambda t$ the samo time I have no doubt that all idea of beating to windward rould be wisely given up, that a great simplification of masts and rigging would be possible when this view is entertained, and that true cconomy in this instance will bo found to consist in using wind-power to go to leeward, and steam-power for action or to go to windwarrl.

Having thus treated briefly of the forces which are to drive our ships, I will next take the forms of ship which ought to be driven; and here I must observe that though no rule can possibly be laid down which will enable one type of ship to satisfy all our requirements for defence and offence, it is most possible to avoid such a stigma as that not unjustly applied by a high naral authority in the IIouse of Lords lately to our modem slips, "that thiey aro neither fit to "defend our shores, nor to cruise at sen." It is not only possible to avoid it, but there is no excuse for even the semblance of such a state of things. Let us see how far the charge may bo a just one. It can hardly be said that a ship is fit to cruise at sea which may be upset by such accidents as a white squall, a summer gale, or even it real hurricane, coinciding with a distubed ocean level, all or any of which may come with no sufficient warning to allow their avoidanco. Neither is that ressel fit to cruise at sea which carries only three to four days full steaming power, and yet is unable to rely on her sails alone for either tacking or wearing with any reasonable certainty, or on any reasonablo distance; neither, again, is that a sea-going cruiser which can turn bottom up if a wave of $20^{\circ}$ inclination coincides with it heel due to sail pressure of $10^{\circ}$ or $15^{\circ}$.

It has actually been attempted, by those who nerer saw a ship except in harbour, to allege that our seanen are likely to handle such ships as aro now giren them, improperly, which being translated means, that they will not be able to keep an engineer's box from taking its position of equilibrium botton up. It is unfortunately an cudeniable fact that if the "curre of stability" be calculated for any of our modern irouclads, it would point to the certainty of their tuming right over directly a given angle of inclination, far short of that which is known to seamen as "on the beam-ends," is reached. In some classes of our modern ironclads, nothing but putting extra weight in their bottoms, which has no ralue except for this purpose, will keep them from turning over in the most ordinary circumstances.

This is not scientific ship building. What England requires from those who call themselves scientific nayal architects is not "curves of stability" slewing when and where her seamen will bo drowned, but ships of stability, which, as long as the water is kept out of them, will 
nerer do any such thing. This used to be tho case once, and ought to be the case now.

Lord-IIardwicke was right in saying that " theso ships are not fit to cruise at sea." Are they better fitted to defend our shores? This is easily settled. First, their draught of water is such as to make them specially unfit for North Sea work, where the principal defenco would hare to be accumulated; and, sccondly, their small number, relatively to cost; and, therefore, small number of guns carried, notwithstanding the size of these guns, make it certain that they are ill adapted for this work also. It is only further necessary to say, that science has long ago shown how in small light draught ressels, carrying the rery heaviest guns, it is possible to defend our shores efficiently; how with floating forts to dispense with endless fortification; not of strong places, but of weak points; and how for sen cruising, the only real requisites are safety, speed, and power of sustaining it. If wo chonse to liaro mailed giants carrying monster guns in order to bo prepared for flect actions, well and good; but they must never be substituted for, or confounded with, either the protectors of our commerce and honour during peace, or the small active defenders of our coast during war, though they may be floating forts and fit for leet action under steam. If the porrer given by Captain MIoncrieff's inrentious be properly utilized, but little armour will be required in sea-going ships, and that little will protect both the vitality of the ship and the offensive weapons she may carry, and yet it will not affect her stability. Turrets, except for smooth-water work and on raft-like vessels, were always a delusion, since they nover have giren, and nerer can give all-round fire, their chief claim to excellence, and norr; that on the gun has been conferred the power of lowering itself behind the side armour to bo recharged, thero is still less renson for their use. No naval architect ought erer to have called that a seagoing cruiser in which it was proposed to carry 800 tous of dead weight on and about the upper deck, unless a form of vessel were taken giving enormous bean, like those proposed hero by tho lato $\mathrm{Mr}$. Elder, and

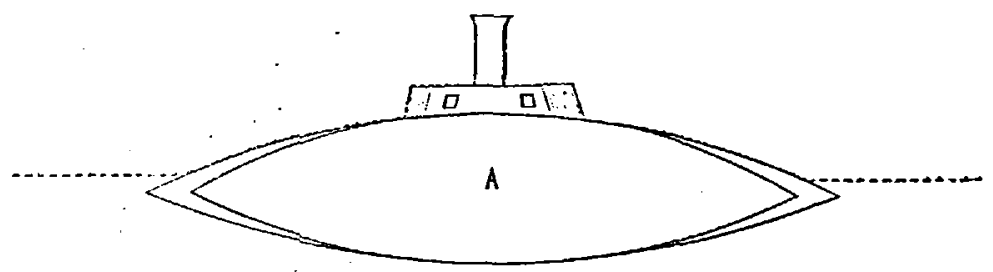

which, for flect work or floating forts such as I have spoken of, would be far more formidable than any ships now affoat. On this head I think the true economy will be to have distiuct classes of ressels for the distinct purposes to be subserved, and to engage in experiment forthwith with this view. The "Staunch" and her" consorts may be accepted as an instalment of what should be done-but far more efiiciently done, for our coast defence; but the liybrid heary draught breastwork "MIonitor" will have no proper place. Secret telegraphic 
communication, a vailable to the coast guard by night as well as by day, which our present telegraphs are not, would place a mosquito fleet, in tho shortest possible time, on any part of the coast they were called on to defend, formidable to the very largest ships of the enemy by reason of their number and small size, almost indestructible by his fire, and by their light draught of water, safe from his near approach. Thus, too, the fullest use could be made of the seamen at the various mercantilo ports in case of necessity. They could be easily trained during peace, and would be always at hand during war. Sucl gun-vessels may be fast, and will certainly bo handy. Is many as twenty could certainly be built for the price of one breastwork monitor, and they would each carry ono gun, as big as any on board of her. I had rather attack two such monitors than half of such a fleet, for the ram or the torpedo may dispose of the monitors at a blow; but how can any one deal with the stings of such wasps as he would have in the gun-vessels, for gunvessels and not cruisers these ought to be, cach carrying, if possible, a $2 i-t o n$ gun, or if not that, as large a one as could be fought and carried? These vessels should never be taken away from their district, but should occasionally be assembled for combined mancuvring. They should be in charge of local naval Officers, and be manned by local seamen. A threatened descent might thus bo seriously impeded, if not driven off in the time that would otherwise bo consumed in calling larger ressels from a distance. for such a descent will nover be attempted near a large fortified arsenal, but at undefended portions of the coast. I know it is said that to land troops in the Crimea and elsewhere, has taken much time, and has proved difficult. I do not believe that this will be the case when an intelligent selection of a deep-water shore for disembarkation allows intelligent and energetic seamen to run the nose of each steamer on to the portion of beach allotted to the troops they carry. I do believe that any nation possessing emigrant steam lines, can land from each of such vessels from 1,000 to 2,000 infantry with ease, or ain equal proportion of artillery, caralry, and stores. I do believe that a few hours of a fogry night would bo sufficient time in which to effect the operation, and I fear that at present no adequate means exists for preventing such a descent. This, again, ought not so to bc, and it is false economy not to be prepared against it. Thus then, there would be three distinct classes of ressel in our Navy not interfering with one another, but all available for defence, or if need be, offence, viz., the light gun-vessel never leaving our const, costing little or nothing for maintenance, for she can be manued by true Naval Coast Volunteers; the floating fort capable of higl speed continued for a long time on an emergency, yet needing no masts nor sails, and therefore no sailors, unless as chiefs or navigators-nothing but artillerymen and engrineers (I speak of the vessels proposed by the late Mr. Elder); and lastly the ocein-navy proper, fast, commodious, lightly armoured, yet heavily armed, cheap during peace and formidable to the enemies' cruisers or commerce during war, frigates of the future, with full and properly disposed sail:power and condensed fuel for use on occasion, so consumed that not a pound of useless weight is carried, with armour sufficient to protect the men at their quarters, but not deroted to pro- 
tecting the whole ship above water. If the hydraulic propeller be used no injury under water likely to occur from shot, would bo fatal. But all this will require experiment, and experiment is the only means of reaching true economy. $\Lambda$ few strokes of the pen may reduco expenditure, but there must be much labour of the brain, and hand too, before true, lasting, economies can be realised.

I will now advert to those economies, real and false, which affect the personnel of our naval power. First, as to the soamen, for to paraphrase Goldsmith-

"Chiefs and their staffs may perish or may fade;
A breath may make them, as a breath has made;
But the bold mariners, their country's pride,
When once destrojed can nerer bo supplied."

That is, in time to be useful. There is little use in ignoring the fact that the modern requirements of our men. of-war seamen, involving: constant drill and discipline, even more than a sailor's knowledge of tho handling of wind power, have gone far to separate the naval service from the commercial marine of England, and it is here the false economy not to keep up a large force of really trained men-of-war's men, providing at the same time by the admirable proposals brought forward here a few days since for substantial reward in continued employment on shore for those who had well served their country at sea, and also providing, as might easily bo done, that during peaco sufficient profitablo employment should be found for those who might be waiting to take their turn at sea. Economically conducted Government manufactories of such articles for naral service as only government requires, might amply fulfil this condition of preparedness for all those eventualities which come so suddenly upon us in these times, and a great deal of the modern man-of-war's-mau's drill could be done on shore far better than at sea.

Contictue therefore and multiply those training ships for boys which are already doing better work than many educational boards, for these supply a real demand, not an ideal one; these mako honest handworkers, not dissatisfied brain idlers. 'Teach them that they aro prized by the State they serve, and shall be liberally, not grudgingly rewarded. Teach them that good conduct will raise them in real and permanent position, according to their real capabilitics, not in false imitations of tinsel rank. Responsibility is often a real terror to those who know themselves well fitted to obey, but also know that the accidents of birth have never fitted them to command. It is not true that any education, still less ouch education as can be given after the child passes into the world of schoolboys, will erer enable all men to be equal in capacity for taking the place of governors rather than of governed among the human race.

Instances of self-raised men are not indeed rare, but they prove the force of genius and character, not the power of education, and here $I$ take occasion to say that, whether for Officers or men, a seaman's best education, as that indeed of all other professional men, consists in teaching him to do as well as he possibly can that which his future life probably will require him to continue doing, not any attempt at a smattering 
of all knowledge, in many branches of which he can norer succecd in being any thing moro than a bungler.

I now turn to the persomel of Officers, in which England has in former times been so rich. $\Lambda$ s eigineers-for the first who embanked the Thames in modern days was a naval Oficer-and many there are now in our Navy who have shown a shill under circunstances of exceptional difficulty, of which eivil engineers might well be proud, for fertility in expedients is a well known quality of naval Officers; as diplomatists of firmness who nerer meddled or muddled; yes, eren as directors of great commercial enterprises in times of peace, I am proud to assert that no profession has ever shown moro rendiness of hand, brain, and heart, than the Navy of Great Britain. But if by an uuvise economy the position of such a professional man should bo rendered to the last degreo uncertain, if, in addition to ignoring merit, it slrould be attempted to over-rido professional claims, then it seems certain that no such results can in the future be olitained as have so largely contributed to the state of England's naval power in the past.

Wo may acknowledgo the difficulties of ever-increasing-half-pay lists and obsolete professional knowledge, but these may bo more reasonably attacked by a truo union between the junior Officers of the Navy and mercantile marine than by ill-treating. old servants; this indeed would be a truo economy, and nothing could more contribute than such a course to root in the hearts of the nation, the most wholesomo of feelings an Englishman can have-a truo loro and reneration for England's naval power.

The Cnarnjrax: Tho present paper has touched upon theso subjects:Fuel.

Sail power properly applicd.

Irotire power.

Forms of ships, and the utilization of separate forms of ships to separate purposes.

Economy of personuel.

If any gentleman is inclined to speak on the subject, and will confine himself to these heads which I hare just read, it will be treating the subject clearly, and will take up less time. The first subject is fucl. If any gentleman is inclined to speak upon that point, we slanll be glad to hear him.

Mr. Bell Galiors : It is a lamentable fact that the ships in Her Mrajesty's serrice at the present time are using an estimated quantity cqual to $4 \frac{1}{2} \mathrm{lbs}$. per indicated horse power. It has also been stated that in a resscl called the "Britan," it has been practically prored, that $2 \mathrm{lbs}$. per indicated horse-power is all that is requisite to accomplish the object of power. The question then comes, why should it ve that 4 l $1 \mathrm{bs}$. should be paid for by the Gorernment of this country, when 2 lbs. is quite ample for the purpose? Thie nest question is this, is our form of propeller best adapted to utilise the fuel required for the production of power? Captain Selmsn has pointed out that with the hydraulic propeller in proportion to the power npplied, you can hare a better result thian from the screr or from the paddle. If that be so, why then is not that used as the correct form of propeller? My last remark will bo this, that I hold equally with Captain Sclugn, and I believe it will be admitted upon equitable principles by crery one present, that if encouragement were given to those who derote their time, gire up their energics, and use their means for the derelopment of science, the country would sare a large amount, science would be promoted, practical results would be obtained, and so much fault-finding, 
so much grumbling, and so many anomalies would not exist, and we should bo all the more benefited by it.

Captain Cosoys, R.N.: I should like Captain Sclwyn in his ansmer to state what he calls "properly-applied sail power." As to motiro power; I only wish to Eay-in a measure to back up what Captain Selmyn lias eaid about the liydraulic propeller-that I do not think that the serrice is quite a mare that the "water propeller" has nerer been properly tried; it has always been tried under conditions where other clements hare interfered with its value, per se. We don't know at this prescut moment-nobody in England can say for certain-whether the "water propeller" is an economical or an uneconomical power for propelling a man-of-war.

Mr. LNDREW MfUnesr, C.B. : Haring had much to do with the esperiments with the hydraulic propeller to tho estent to which thes wero carried out by the Admiralts, I am glad of an opportunity of baching up what Captain Selwjn said with respect to it in combination with sail power. I lonk upon tho results that may set bo obtained from it in that respect as probably superior to any that hare been obtained from any other steam propeller in combination with wind. With the hydraulie propeller the mater is taken into the ship as she proceds, and immediately acquires the relocity of the ship, and is carried with it, and it is then acted on by the centrifugal pump in the interior, and driren out at a velocity in accordance with the speed of the enginc. The relocity with which tho rater is driren out, and from which tha power of propulsion is obtained, is alwass in accordance with the speed of the cugine, and it appears to me that nothing is lost in the action of this propeller by tho speed with which the ressel may be going under canras at the timo when it is set to work to act in combination with the sails. That is not the case either with the scres propeller or with the paddle whecl.

Captain SeLwrs; 3ray I draw the speaker's attention to the fact that I introducc a perfectly new consideration on the point. It is that the hydraulie propeller is a self-contained power, like that of the rocket, and that the more porrer you put into the ship the nore will be the effect on the ship, wheress that nerer can be the case with any propeller which depeads on its area of prosh for its porrer orer the ressel.

Mr. IIUnnaY : I was speating about the propeller, simply, when called upon to act in combination with wind sail power; that, if a vessel is already going ten knots under canras, if jou put on steam power with either serew or paddle-wlicel the adrantage gained is slight. I hold that with the hydraulic propeller, supposing that tho ship is already going ten knots, she will get the whole adrantago of that porrer, the same as if starting and proceeding with that alone. I hare adrocated that riers for a long time. I am sorry that the circumstances hare been such connected with the "Waterwitch," as to hare prerented tho Admiralty considering it right to continue the experiments. Mrore experiments are particularly wanted. We know nothing of the subject, we neither know whether to send ont the water through a small orifice with a high relocity, or through a large orifice with a slower relocity. We know nothing of the form of the pump. I disagree entirely with the form of pump in the "Waterwitch," but that is in the hands of the patentec-not in tlo hands of the Admiralty. Intending to speak upon this, I thought I ought to speak upon all the point 3 in the paper at the same time. It is ner to me to diride the points in this way, otherwise I would hare mado a fer remarks upon the economy of the fucl. But, perhaps, it will be more in order that I should do that afterwards. (Go on.) I should only say that Captain Selwyn spoke of the compound engine in the "Briton." I would call to his memors that that is not the first compound engine that has been used in the Nary.

Captain SeLwrs: I said it has long been known in the mercantilo marine.

IIr. JICRRAY : But that is not the first engine tried in the Nary. There tere three ressels, many years ago, tried competitirely. Tro other ressels, tho "Scrapiz" and the "Crocodile," were fitted with compound engines by the late Mr. Humphreys. There were some points in which some difficulties accrued in their working, and to my great regret an order was giren by tho Admiralty, and a backuard etep was taken, to restore the engines to single acting cylinders. As a passing remark, Captain Selwyn will forgire me, he said that the constant temperature of $100^{\circ}$ meant notling. 
Captain Secmrx: It means nothing as regards the evaporation of wates.

Mr. Merrar: Let me explain what we understand by it. I think the audience will easily understand that if we take a quantity of water nt $33^{\circ}$, the coldest water jon like, or take it at $60^{\circ}$, and put it to boil on the fire at that temperature, it will require a little more fuel than if you put it on at $100^{\circ}$. That is the reason why wo take $100^{\circ}$, because the trater put into the steam-engine boiler sometimes comes from the condensers, and it is slightly warm, sometimes $80^{\circ}$, sometimes $90^{\circ}$, sometimes $100^{\circ}$, and we allow for those fer degrees.

Captain SeLWY: : It docs not gire the unit of heat.

Mr. IItrRas : It simply gives what I state, that you will eraporate more water if sou put it on the fre at $100^{\circ}$ than if you put it on at $60^{\circ}$, because it does not require the fuel to raise it from $60^{\circ}$ to $100^{\circ}$.

Captain SEITrN: If you take from a temperature of $212^{\circ}$, it docs not gire you a more accurate measurement of the unit of heat and its work done, as if jou had so taken it, as Professor Rankine does, from 212.

Mr. Irorbay: You can always bring it up to $212^{\circ}$. We take the rater as put into the boiler, whaterce that may be, $40^{\circ}$ or $80^{\circ}$, and bring it up to the $100^{\circ}$ as a standard.

Captain Scotr, R.N. : Will you allow me to make one remark about the hydraulic propeller (I hare not spoken upon the subject before), that it has always appeared to me to be a most impertant mcans of propulsion. At present nio cannot turn our long ressels, but Admiral Inglefield, who is now engaged in working out the application of the hydraulic to turn the propeller, is also paying considerable attention to the subject of applying the hydraulic to turning the ressel herself. When the hydraulic propeller, as a means of propulsion, is combined with the means of turning the ship, you will, I think, hare every adrantage that can possibly result from its usc. I cannot but concur in what has been said as to the inconclusiro character of the cxperiments that have hitherto taken place. As a first experiment on a large scale, the results obtained in the "Waterwitch" are rery remarkable. Many of our ressels with their exposed rudders are rery liable to damage. Their engines also are much exposed. If we can by means of the hydraulic propeller get not only a means of propulsion, but also an ausiliary means of turning those ships, eren if your main engines break domn, you will be still enabled to bring your broadside guns to bear by turning the ressel. I look upon the hydraulic as one of the most important means of propulsion that las been derised, but think it is still raluable as a turning porrer.

Captain SeLwrax : I hope cugineers will not be deterred from speaking after considering the extraordinary result (sec Appendis to paper), shown on that table, because I inay say that there has been no continuous craporation of water ercr obtained in any country from that common type of boiler, anything equal to what is shomn there. That is the first time that it has been done. It las been done as experiments on a small ecalc. I accurately checked them, and rarious other conditions. For nine months that boiler was going on making steam.

Captain Fassox, 1st Surrey Rifle Volunteers: I am a Volunteer, but I hare taken great interest in naral matters also. I should, therefore, like to put one single question. Can such a ressel as is shown in the diagram which Captain Selwrn has dramn, and which secms to me rery much to resemble a form of vessel which was lectured upon here some time ago-a saucer-shaped ressel-sail? The diagram only gires the midship section of that ressel.

Captain SeLwrs: That ressel can proceed under sail with the utmost facility. The longitudinal scetion may be prolonged into any form of the oroid jou choose to adopt, or it may be the complete segment of the eplere.

Mr. Haxsox: I answer you directly, in order that no argument may proceed on a false basis. This is by Mr. Elder not put forward as the only shape in which you may put a ship, but as being the segment of a sphere, or a body approaching to a sphere, the greatest containing body with the smallest perimeter, with the least draft and the greatest speed.

Mr. HIDE: Perhaps you will permit me to remark that the paper which the gentleman just now enquired about, was read by me some two jears since in the 
theatre of this Institution. It was a paper on ships with deflecting sides. Subse. quently, the late MIr. Elder read a paper on circular ships. The diagram which Captain Selwy has drawn represents simply a cut or section through the middle of that circular ship. The ressel that I proposed, and which I hare adrocated for some 18 years, lias the same section, but is not circular, but an clipsc, an elongated oral, still laring deflecting sides. The object of haring deflecting sides in preference to rertical is simply this, that all artillergmen, all constructors of guns, naral Oflicers, and those who know austhing about modern artillery, agree that rertically. sided ships cannot keep out the projectiles of these modern days. We hare just coustructed a gun known as the 35.ton gun, which is said to be able to throw a shot throngh a 12-inch plate at a distance of 2,000 jards. If that be so, and we hare no doubt it is, what class of ship can sou build which will be capable of kceping out theso direful projectiles of modern dnys? Perhaps Sir George Sartorius will remem. ber that I had the honour of some conrersation with him npon this subject two ycars ago. The dramings, diagrams, and models were left in this Institution for some days after the erening of the paper, so that any gentleman might sce how simple and hor conrenient a ship could be built haring sides at an angle of some $221^{\circ}$ or $30^{\circ}$ to the line of fire. It is well known that experiments at Shoeburyness and other places shom, and eren in actual warfare we bnow, that if a shot hits unfairly a surface, that shot passes off and ricochets. Now, why cannot that principle be emplojed in the construction of our ships? It can. There is not the slightest difficulty about it. If the ship's sides are presented to the line of fire at a suficiently low angle, there is no projectile that can be thrown from a gun that will pass through them. This is now what most naral powers are secking to obtain. I can tell you that the Prussians at this moment, in their arsenal at Fiel, are making experiments, and are, in fact; constructing ressels of this class. That is a fact which ought to be known to the authorities of this country. It is perfectly plain tlut in all personal cneounters you attempt to parry a blow instead of recciring it. The art of fighting in defence is to parry a blow. Why not then inrestigate a system which presents to us at least a common-sense plan of kecping theso direful shots out of our ships? If you will allow me a moment, I will male a midship section to show cractly the form of ressel that I allude to. (Drawing the same ou black board). The plan of the ship rould be an clongated clipse or oral, with sides at an angle of $22^{\circ}$ to $30^{\circ}$, and the turrets, if such a ressel had turrets, rronld be placed one at each end. Now, the armour with which thesc ships would be protected need not be so thick ngd so heary as the armour used in our present ships. I hnow the argument has been used, that tho long surfaces in the deflecting sides added together would make a hearier armour than if placed rertically; but the reply to that is this, if sou place it rertically, shot will go through it; if sou keep it at a low angle, the shot will pass off by ricochet. All sailors, all artillery Officers, who hare seen the models-and I shall almass be pleased to show them-tell me that this is the form of ship rhich is most likely to keep out the shot of our modern guns. It is obrious, if the Prussians are giring attention to it, and if naral Offecrs generally and artillersmen are giving attention to it, that it has some adrantages. I hare no donbt that these immense gums which are now being manufactured, will of necessity compel such a system as this to be introduced in the construction of some of our future slips.

The Crarnucus: We now come to the utilization of separate forms of ships to separate purposes.

Captain SELTSA: What is meant by separate forms for scparate purposes is that to which I adverted to, namely, the threc elasses of ressels, one constructed solely for shore defence, in which will bo the best utilisation of our coast roluntecrs; the eccond also for harbour defence during an inchoate phase of war when the requirements are not fully defined for fleets, and then they are useful as floating forts afterwards; these mould come in for eren flect actions near home; and the third, occan cruizers. The "Staunch" and her consorts are existing examples of the first class.

Captain Moscriefr: In reference to this part of the subject, the smallest gunboats which hare bcen uscd in the Nary, namely, the "Staunch" class, hare the adran-

roL. $x y$. 
tage of cconomr, when looking at the price per gun in these ressels in comparison with the price in larger ressels. I have before me a statement relating to sereral classes of ressels. The "Staunch" gunboat, mounting a 12-ton gun, is put down at $£ \mathcal{G}, 000$ per gun : the "Inconstant," unarinoured frjgate, nt : $£ 13,000$ per gun ; the "Caledonia," with 41 inch light plating, mounting ciglit 6 -ton guns, six 10-pounders, and trelre 63-pounders, $£ 11,500$ per gun; and the "Royal Sorereign," turret ship, with $5 \frac{1}{2}$ inch plating, mounting fire 12 -ton guns, $\$ 10,000$ per gun. In the hearier armoured ships the expense per gun increases rery much. "The "Sultan," with plating from 9 inches to $G$ inches, and 12 -ton guns, costs $£ 31,000$ pcr gun; the "Derastation," a turret ship, with plating from 12 inches to 10 inclues, with four 12 -ton guns, $£ 09,000$ per gun; the "Glatton," turret ship, from 12 incles to 10 inehes, and with two 12-ton guns, costs $£ 81,000$ per gun. It is therefore evident that if theso small resscls are well suited for $\Omega$ special serrice, it rill be more economical to employ them for that purpose than the moro expensire hind of ehips.

Captain Scorr: I think Captain Mronerief has made a slight mistake as to the guns. The "Derastation" guns are 35-ton guns, and one of the 35 -ton guns is at least equal to a dozen of the smaller guns be has named. The "Glatton's" are 25ton guns, and the "Inconstant's" are 12.ton guns.

Captain MoscricrF : I beg your pardon; I hare made a mistake.

Captain Scorr : Of course it mas merely a mistake. Fon must remember that. efleiency depends upon what ecrice jou want the ressel for. Tho "Inconstant" is a ressel that you can send all round the world. She is a fast cruizer under sail, and can carrs heary guns and a great number of men whererer wanted. Nobody can say that the "Staunch" can do such duty as that; she is morely a conster. As regards the calue of the "Staunch" class, there I perfectly agree with Captain Moncricf:. There is no doubt that these ressels are of rery high ralue for protecting our harbours and coasts, but $I$ do not think you cau compare them with ressels that are not only good for lome serrice but good for foreign scrrice, and good for any other serrice.

Captain SeLTry: May I recall Captain Scott to the subject of the paper, which is, special ressels for spceial services.

Captain Scorr : Allow me to sas that I am perfectly in order. I am spealing of special ressels for epecial ecrices, and will now say that I think the "Staunch" is rather too small for her intended scrrice: We want a ressel of similar type, but capable of carrying the heariest gun, riz., a 25-ton or 35-ton gun; she must therefore be somewhat larger than that ressel is. Not only should she be able to protect our omn shores, but she should bo also able, if it were requisite, to carry her guns across to the acighbouring shores. I think the power of England depends upon offensire power much more than upon defensire. 'To come to the nest class of ressel. You want fast unarmoured eruizers with the lighest sperd, and the other qualities that Captain Sdngn has stated. As to line-of-battle ships, you want vers powerful ressels that will stand a great deal of hammering. We lare now got such ressels. Whether powerful ressels will be required hereafter more than lighter ressels is well worthy of consideration. Still, our heary ironclads are excedingly porrerful ressels, and they will enable us to hold the empire of the sea, whilst with fast unarmoured cruizers of sinilar type to some we hare built and are still building, we could chase any other ressels off the sea. Onr "Staunches" and proper const defences would then make our island perfeetly sceure (so that we might sit down at rest and feel contented with the assurance that we had not gone far ont of the way in the line we had taken). I do not think we lare jet got so far as this, for we want a great many more fast unarmoured cruizerz, and me mant more ressels of the "MIonitor" type, and a great many more "Staunches." Instead of a few of such resscls haring been ordered to be built, we ought to hare already built a lundred. Then, with regard to what has been said of experiments, we are entirely deficient of definite experiments. The cost of most of the gunnery experiments that liare been made, I look upon as mones thromn array. IFe really do not yet hnow what the actual power of our guns is, although wo lare gone on piling up armour on the sides of our resscls (in my opinion tre put on a great deal too much) without knowing what armour wc 
really require. We hare been firing at Shocburgness upon plates fastened in a particular way, and supported in a manner that they are nerer supported when placed on a ship, and we are now going into further experiments of similar character which will therefore be equally futile, for they camnot yicld any practical results. Without mating too long a story, I wish to sas that our falso economy in making cheap and incomplete experiments is one of the most dangerous things at the present time. This is an age of progress, and unless we carry out complete experiments on a comparatively small ecale, wo shall be hereafter trying in war experiments on a largo scale, which may prore almost fatal to our supremacy.

The Cinsrasix: The next subject is the cconomy of the personnel.

Captain SeLwry: By that $I$ mean the Officers and the manning of our ships.

Commanler BreNT, R.N.: I cordially ngree with Captain Selwyn, that our men should be well trained. It is a subject of great importance to all naral men, to the Tary, and to the country in general. That part of Captain Selirgn's paper might almost form a paper on "internal organization of the Nary." Of late years, during a ship's commission, we hare been trying to teach our men almost too much. Captain Selwyn said they should come on board perfectly trained. I quite agree with him, and if we run orer wliat we hare to teach the men during a commission, at the end it is found they are not perfectly tanght, crecpt, of course, the ferr men who come from our gunnery establishments. As he said, we shall hare ressels mith guns, therefore we want good scamen gunners. We also want our men to be good sailors, able to do their work in all parts of the ship, and under all circumstances. They must also be fair solclicrs, able to do their work in a company and in a battalion, and also work field guns. "They must be fair strordsmen, and to acquire a thorough knowledge in each one of these points, takes almost a lifetime. The men should come on board ship perfectly instructed in these points, and then we should hare to teach them seamanship. I think a part of the year should be set aside in which erery ship in the serrice should turn herself into a gunnery ship for a time, and run through the gunncry and the military duties that seamen hare to learn now-a-days. It is of great importance that wo should not hare perpetual instruction going on while the ships are in commission. Seamen gunners come on board, and we hare no tronble with them, but no Gunnery Lieutenant is satisfied with his rork at the cud of the commission; he has quite broken down, and if you ask him, he will tell jou he has taught the men in a certain way, but he is not satisfied with the result. A man-of war's man has much to learn, and he should come on board ship knowing his gunnery work. I think we ought to hare larger gunnery establishments, in order to teach the men, so that you should start on your commission with erery man on board, exeept the boys, perfectly instructed, then jou would merely hare to keep up that knowledge and teach them to be sailors.

Commander P CSEY, R.N.: I should like to ask the last speaker a question with regard to what has been sail about gunnery establishments; is it net a fact that after seamen hare been mell trained, and hare been a loug time on board in a seagoing man-of-mar, and have passed out of their drills, thicy are still hept on, day after dar, in musketry drill, cutlass drill, and gun drill, and whether it is not that which disgusts seamen so much with the idea of gumnery?

Commander DEENT : I do not think the seamen are disgusted with tho gumners, because jou find all the best men go to the gunners cstablishment, but what is done is that they are nerer perfectly taught in sca-going ships, they only get a snattering. I know that no gunners Oficer is satisfied with his work at the end of the commission. The drills get $s 0^{\circ}$ broken into by the ordinary work of a man-of-war that nothing is perfectly done, and as Captrin Selwyn has said, we want the men to be well trained and well taught before they go to sca.

Captain Corour, R.N.: I understand Captain SeIrJn to say that he thought the times were such, that the Nary less and less approximates to the merehant serrice, and $I$ understand him that we must depend more and more upon the Rojal Nary, and less and less upon any help we might get from the merelant serrice. I think that is only true to a certain extent. If me, as Naral Offecrs, were at the head of the gorernment of the country, I hare no doubt whaterer that we should be able to depend entirely upon our orm men, but the gorernment of the country is such that 
political exigencies will perpetually necessitate the pricking of the Nary as yor prick an india-rubber ball, and permitting it to collapse for giren periods of timc. I think the only way to puif this ball up again in time of danger is to kecp, as we are now becping, a totally separate Reserve in the merchant scrvice, that we cau call upon when we want them. It is a body of men not likely to be touclied. It escapes in the estimates, it does not cost much, and when politicians take a pull at the Nary, they are unlikely to take a pull at the Naral Rescrve from the merchant Ecrrice. Consequently, we alwass have that body of men to fall back upon in times of panic, which ineritably follow a time of great economs.

Mr. AESIEN, O.E.: I wish to speak upon the subject of fuel. I hare only to state that I hare deroted cighteen years of sharp practical inrestigation into the use of peat as a fuel. That coal is derired from peat is positirely certain, but it is the work of $6,000,7,000$, or 8,000 years before it is sufficiently condensed to form coal; but by mechanical application you can drire the air and water out of peat. It is a fact. that our British peats hare at least 75 per cent. of water in them, which wants dricing out, and liow to drive it out has been the problem. I lare had the good fortune to suceced in doing it. What was wanted was not compression, but condensation,-how to drire out the air and water, and then present the peat in a mass. that mould be applicable for the furnace. I hare eeen experiments tried in Ireland. They make the peat into the form of a dise by driving it through a cylinder and cutting it of about three-quarters of an inch in thickness. Theso were thrown into the furnace, and it was found that they lad to be pulled out again to be broken up with what is enlled the elink hammer. It struck me the best thing was to form a ball. Parties hare said to me, "Why don't you cut it into squares or cubes ?" My reply is, that if you cut it into equares-crery man who has been - on board ship knows that if jou hare to stow a largo bulk of artificial fuel in the shape of squares or cubes, you must ecnd in a man to craml on his hands and knees to stow it.in it 3 place, and send him in agan to pull it out; whereas in the shape of a ball the peat will roll itsclf out when it is wanted. Then $I$ found it was impossible with any machinery me hare, to produce a equare or a cube so condensed as the ball in my liand. I then produeed this article in the shape of condensed peat fuel. It is 50 per cent. hearier than coal, and I gire you my word, for it is not a mere assereration, that one ton of this will do nearly three times as much as the best hand-picked coal that was erer dug from the mine. This has been prored by experiment, and it only wants to bo prored on a large scale by access to powerful machinery sufficient to make 50 tons a day. I do not make these assertions as mere assererations, because they hare cost me years of reflection. Ifad $I$ been a man of wealth, and could hare put my hand on a few thousand pounds for machiners, I should not haro to ash assistance, or to ask the co-operation of any man living. I would hare gone on and spent my last farthing to prore it. But I hare been prerented bringing it forward for want of means. I hare now orders from the Peninsula and Oriental Company, from the West India Mrail Packet Company, from the Almiralts, from the dockyards, from the Underground Railway, from Hong Kong merchants, and last, but not least, from Russia. The Russians hare offered to take all the material I can make for St. Petersburg and MIoscorr. Unfortunately I hare not the means of making it. I am proud of my country in crery other respect, but it is an unhappy country for a man who is born with a genius or brains; ho is treated like a nad dog iustead of being treated as a first-class mau, as he would bo in dmerica. I appeni to any American present, whether, if I had produced such an article as this in Boston, I should hare passed a fortnight without haring a number of friends around to tako it up, but in this country I must starre, or go into the srorkhouse. The object I hare now is the introduction of peat as fuel, so that the Secretary of the Nary should be able to eend a ship of war out to sea with three times the quantity of fuel that sho can carry at present. If that is not an adrantage to IIer Majesty's Nary I do not know what is.

Mir. C. F. T. Yodva, O.E.: The paper read by Captain Selwgn touches on the cconomy of flects, both in form and maintenance, construction, and so forth. I should like to make a few remarks. First, I am glad to hear that these experiments with liquid fuel hare becn carricd on for so long a period as nine months. I have 
scen a great dcal of the fuel myself, and it is perfectly safo and perfectly efficient. It has this great adrantage, that it docs not deposit a non-conducting material on the licating surface like coal, therefore jou get a greater effect from the heating surface. In regard to the economy of our ships, the other day I was going orer the figures of our carlier ships, such as the "Achilles" and the "Warrior," and con. trastino them with the results of our later ships, the "IIercules," for example. The engincer's question is this. Here is a weight of a giren amount, mored in a giren time at a giren relocity, at an expenditure of a giren amount of power; and the teneration of that power necessitates the expenditure of a certain amount of fuel. I find, taking the "IIercules," and comparing her with the "Achilles", she gires 40 per ccnt. retrograde cconomy, that is to say, costs 40 per cent. more in the way of fuel to more that ship (I am speaking of the "IIercules with all the modern improrements) at the same relocity as the "Achilles" some cight or ten years ago with the old engines. I hare.Mr. Reed's book, and he states that the new engines with all the latest improrements go to $3 \mathrm{lb}$. or $3 \frac{1}{2} \mathrm{lb}$. per indicated horse-power, and the old ones go to $4 \mathrm{lb}$. and $4 \frac{1}{2} \mathrm{lb}$. I take the crtrene in both eases, that is to sas, taking a giren amount of work orer four years for both ships, that the "Hercules", would use 11,000 tons more fucl to do the same amount of work, moring at the same rate than what the "Achilles" would do. I do not fund that we hare got an cconomy by these rery short stumpy ships. I do not say that wo must hare ships so long as the longer oncz; still I am satisfied that these rerr short ships are neither cconomical in the first cost, nor are they economical in the results obtained by burning a giren amount of fucl.

Captain SELWYN : Cáptain Colomb has asked what I meant by "sail-power properly applied." I think if he has time to look orer the paper he will see that I lo"d domu an axiom, which as far as $I$ am aware, has not hitherto been noticed. It is that sail-power should nerer be employd where steam is present, to go to windward. That is a wrong application of sail-power; and inasmuch as with the rery best beating, Jou can only go to windmard tro miles in one hour, jou had better do it with stcam direct. There is another point which Captain Colomb did not, perhaps, quite understand. I said that sail-power could be applied without masts and sails. It secms tery curious that wind-power could be applied without masts and sails. It is absolutely and perfectly true, howerer, that although the horizontal windmill only gires out about 33 per cent. of the theoretical power, yet that that power applied to the propeller will do more mork than if jou applied the full power of the ordinary sails in propelling a ressel to mindward by beating. I am speaking now of a case in which, for other reasong, jou wished to do amas with the existing masts and sails altogether: you can have such wind-power still, as will propel your ship if the engincs breali dorn. That is what I call the scientific and true application of sailporrer; not relying upon what we hare done in other times, under other circunstances, but cousidering what can be done and what ought to be done for due economy in the present time and under present cireumstances. Mr. Manson asked what will be the length of the ressel I mentioned. That question I pretty nearly answered. The ressel I referred to was proposed by the late Mr. Elder, and I quito recognise the ralue of his proposal-not at all with regard to any shot-deflecting propertics it might possess, whieh are outside the question; but with regard to the peculiar fact that this is the only shape of ressel that will gire you the highest confaining power, because it is a segment of the sphere which is the greatest containing body. It is the only ressel which will gire you, with great capacity, fine lines to be rapidly driven. It is the only ressel which, with a minimum of armour, can be made to gire the raximum of security. It is the only shape of ressel which will bear the weights placed upon it high up, which no.decp draught breast- rork monitor will do with safety. It is, therefore, worth considering, when we hare to talk of a flect which will manceurre readily and handily at sea, in columns or lines, as it may be desired, under steam alone, with rery liberal limits as to the duration of that steam, if these improrements. be adopted,-capable at all times of ramming an eneng, but not of being rammed except by a siwilar ressel, and then rery incfiec. tually; capable also of being propelled by hydraulic power which will set at nought that newly inrented demon, the torpedo. The great ralue of the hydraulic porer is 
this: if it were proved that it nerer could surpass the screw or the paddle, there would still remain the fact that it pumps the ressel out with the full power of the engine cxerted, while it is also propelling her; consequently, no shot, no torpedo, eren, in a well-constructed ressel, could sink the ship. I quite agree with Captain Colomb that such a mater-propeller mas rers incficicutly and rery ignorantly tried; and those wlio tried her were satisficd to relegato her to the things that were, after haring proved that the rerg first of such propellers was equal to the best serew they had built on tho same lines, and with the eame dimensions. With regard to Mr. Mrurray's obserration on the compound engines, I ben leare to point out that I did not say at all that compound engines would do ereryiling for a man-of-war at once. But what I did say was this, that it is a scandal to the Nary to sce a dozen such as the " National" steamships from Lirerpool running to-day, dercloping 800 horsepower, on less than $2 \mathrm{lb}$. of coal per indicated horse-power per hour, while ouly one resscl of the Nary has arrived at that conclusion, rilich jet has not arailed to chango the practice of wasting fuel in other ships now building. If people mill ignore inrentors and will nerer be contented to tale up au improrement until, by passing through all the phases of mismanagement, they at last arrire at the true practice of the inrention, instead of asking the inrentor to do it for them, then I say it is not ronderful that that which is done by the mereantile steam ships in oiro year, cannot be done by the fary under ten jears. I recognize the diffeultics under which oll ofleials laboux. I recognize the tendency in this country to cut domn rotes for experiments, and to throw diffeultics in the way of incention. But I say in my paper, and I repeat bere, this ought not so to be. With regard to the calculation of eraporative effect from a certain temperature, I hare shown the calculation from $100^{\circ} \mathrm{F}$. as well as from $212^{\circ} \mathrm{F}$. It is obrious to anybody that as it is not from the changing heat at which water may be pumped into the boller, but at the constant degree at which water will make steam, the calculation ought to start, and that has been considered by all philosophers, and ought to be considered bs our siaral authorities, if they wish to get true comparative results from fuel, I think it is obrious tho sooner they change and work from the constant of $212^{\circ}$ instead of $100^{\circ}$, at which no steam can bo generated at all, the better. With regard to Captain Scott's obserrations on the hydraulic propeller, I hare already stated that it has the adrantage of unsinkability. That is a great adrantage. It has also the power of doing a way. with the training of guns, because the ship can be trained with the hydraulio propeller in less time, giren a certain shape of slip, than rou can train the gun, and will giro all round fire as fur as it is useful at sea. When you add to that the fact. that after all a ressel of 3,000 tons, propelled at the rate of cren eight bnots an hour, has a superior effect to the biggest shot that was erer fired, you will understand how raluable it is; Jou hare a ressel so propelled that at any moment and in anj direction she can be sent with full relocity against an enemy. Those who hare passed through a collision in a railmay train know how sometling like 300 tons, which is the fair arerage weight of a train, going we will say at fifteen miles an hour, will compare rith 3,000 tons going eight miles an hour. Is there any doubt that tho attacking ressel in ramming must always be the superior. Fou necd not consider whether you hare any guns on board, prorided you hare got a sufficint steam propeller to use in this way. I do obserre on this with the more pleasure that I bnow I am in the presence of an authority who has nerer failed to adrocate that form of offence. Mrr. Ir yde spoke of the dellecting sides. I must say that there is a certain law connected with deflecting sides. It is this. Gircu a weight of armour, it does not matter whether jou dispose it on an incline or upright; i.e., in the one ease less height or surface admiț of more thickness, in the other extended surface necessitates less, but deflective power males up the difference. There is this difficulty, that the moment jou get alongside a ressel only slightly elerated abore yourself in height, and able to fire domn upon you with properly constructed gun carriages, all your fancied security disappears at a blow; and if you get under a high fort like the Wasp battery in the Crimea, you will get stung right through from top to bottom. Deflecting sides do not then come into play. There is another objection to deflecting sides. Deflecting sides are rery true, in an enginecr's point of riew, when you can secure a smooth sea and no lieel or roll. But I hare not jet found out the time when a ship 
is on an cren kecl at sea. Our Chairman has scen many Jears' serrice at sca, and I hare no doubt he has equally failed. With regard to the cost of the breastrork monitor compared with the small "Staunch," Captain Scott did not quite recollect that a $4 \frac{1}{2}$-inch plating will not kecp out angthing. 'ilhesefore we had better compare it with a ship unarmoured altogether than with one which has got $4 \frac{1}{2}$-inches of plating on her side, for not only will she not keep out any shot, but she will - contribute to the deadly effect of that shot by the pieces of plating which trill be clriren in among hex erem. The bresstwork monitor may carry, I will say, a 35-ton gun. Now, I do not know any reason, I hare nerer jet heard any reason, why a ressel 100 feet long should not carry a 35-ton gun too. If jou build her of iron, and build her properly, and do not insist upon having a carriage which transmits a great deal of shock horizontally, which Captain MIoncreif's carriages will perer do, you take aray that strain which has hitherto prerented us from carrging the meight in a ressel of small size, and fou prerent all that dangerous shock which migbt sliake eren an iron resscl to pieces. I say that a resscl of 100 feet long and 12 fect beam will easily and properly carry on Captain MLoncrcifr's carriage eren a 35-ton gun for coast defenes, - not to go auy further than the coast, - to be properly manned with a small crew, such as can be giren to a gun-carriago properls made and working itself, properly supplied with shot, not supplied with prorisions and sails, which arc ouly necessary for ocean cruizing, but so efficient that she will gire us back that perecentage of loss which we nom hare to pay for panics.

A VIsitor: Will jou Eay what depth of hold will bo required for Captain IIoncrieff's gun-carriago?

Captain SEwwr: : I think if you say fire feet draught jou could easily manage to do that on certain lines.

Captain MroxceIEFF: It rould requiro a littlo moro displacement.

Captain SELwrs: You may give more width. I am not asking for rery lijigh speed. The displacement fou say must be more.

Captain Moxcriefr: 16 feet beam.

Captain SELWYY: We will take it at that.

The Trsitor: The gun is to be lowered below the water line.

Captain SELWXx: Not necessarily so. It may be so lowercd. It will not do if it is a 35-ton gun, seeing that it is 9 feet in the breech. That is how thes are made now. It is to be hoped that they will be made less cumbrous some da5. But the cost of the breastwork monitor is compared not with ono guu,-I think I understate it,-but with twenty guns in twenty small ressels. I know some gentlemen who will undertake to construct such ressels for rery much less than the "IIotspur," that shall carrs quite a formidable gun enough to prercet a landing on our shores.

The gunnery question and the necessity for training our scamen comes next. Here I must remark that I did not suppose it was possible to put on boird men-of-rar, men thoroughly trained to evergthing they could learn on bourd a man-of-rar. Nor do I think it rould be desirable to teach them without that life at sca which is, after all, true training. But they can learn certain thing; better on shore than at sca. Among those things nre the drill of strordsmanship, military drill, shooting with the rifle, and probably a certain amonnt of the shooting which will be required by the artillery, not that which refers to shooting at moring objects with large artillery. But I propose that this should be done, that the whole of the necessary forces should be kept up for manning our Nary in time of war; that that portion which is not employed during the time of peace should be so trained and so managed as alternately to take its place at sea, and learn that training, too; that while on shore it slould not only be drilled and trained, which could bo done in these matters that $I$ hare spoken of, which would occupy a small portion of their time, but that the remainder of their time should be occupied usefully and cconomicalls as produccrs. Constant drill has been spoken of as disgusting the men. I hare no doubt whaterer that erers man thinks himself perfect as soon as he has got a certain amount of proficiency. But I nerer saw the man who could, without detriv ment, preternit in cither arts and arms, the constant practice of those pro. fessions, and though the drill may in some cases be carried too far, yet I think it ought to be Ieft to the instructors on the spot, and, then, I liare no doubt. 
whaterer that it would be done properly. As long as erergthing is centralised, and no judgment is permitted to those who are alone capable of judging by reason of their presence on the spot, so long will you hare such anomalics as that; with increased expenditure you only get rorse results. Captain Colomb compared our Nary to a puffed ball, and I think not unwiscly. But you must recollect : that if you get men who nerer haring been in the Nary, are utterly untrained to the work of the Nary, and who, by being exercised at a $32 \mathrm{lb}$. gun on our old carriage, would nerer learn to work one of Captain Scott's or Captain Joncrieffs guns, I am rather inclined to think that that trust in them rould be a puffed ball. I do not like the idea of a Naral Reserte which is to be relied upon in war by those rery naral Offecers who do not sce it during peace. Afr. Austen spoke rer's largely of peat and its mechanical application. I say distinctly, and I lope Mr. Austen will take it to his heart, because it mill sare lim a great deal of time and a great deal of money, that mechanical appliances for condensing fuel can nerer compete with nature where she supplies the article alrcady condensed, or where that condensed fuel is to be had as the refuse of a paring chemical process for other purposes. More than that, peat can only be made up of carbon, with a rery small and inefficient proportion of hydrogen and some oxjgen. The purest carbon known is the diamond, and that diamond, if carricd into its most perfect combustion, can only craporate $15 \mathrm{lb}$. of water per pound of diamond. SIr. Austen can nerer hope to get his peat into the condition of the diamond. If he does, I rould adrise him to sell it as diamond; if he does not eren do more, it is not possible to get out of it more than $15 \mathrm{lb}$ : of water per pound of diamond. This is not three times the work of coal. If he can prore his point, then there is a new practice in opposition to tho thicories of all the chemists of this and of preceding ages, which will enable him to give us a meelanically condensed solid fucl superior to coal. I will draw his attention to another subject. To use fucl as a gas, we do not use it as a eolid. 'To conrert a solid eren into a liquid, crpends a certain aroount of heat which is so used, and which is not arailable for making stean. To conrert the liquid into gas takes up another proportion of heat; and all that heat is taken away from the effectual work donc. Consequently, jou nerer can hope, by using a solid at first, to get the same result that you would get, were you to use first a liquid, or better and secondly, a gas. The best form in which to obtain combustion is that of gas, which requires little or no expenditure of heat to separate particles before entering on combustion. With regard to liquid fuel, JIr. Young has truly said that it is not dangerous, that it is not difficult to burn, that it requircs no stoling. This is the result of nino months' experiment at Woolwich; I do not say that we were at it day and night, but were at it nine months consecutirely. It has sinee been dropped because the expcrimental rote of the House of Conimons did not enable us to go on with it. There is the state in which rests one of the most important discoreries with regard to the due economy of fuel. And, recollect, I am not the inrentor, nor hare I anything to do with it; I am merely the scientific adrocate of the question. There rests one of the most important discorcrics, which rould at once enable a verse. which now gocs, we will aszume, with a giren quantity of fuel, ten days at full stenm, as the old stcam line of battle ships did, to go twenty days, and if she had compour engines, to go forty dnys with the same. Fow, that is an enormous econony; it does more to solve the whole question of Steam versus Sails than anything i can think of. It introduces a net ficld of inprorement. My whole paper is deroted to the object of proring that applied scicnec can produce more cconomy, if we attend strictly and closely to it, than can crer be accomplished by tho nost economical Chancellors of the Exchequer, or by the most cconomical Ministries, and this with a rast increase of real cficiency.

The Cusirstax: We hare had a rery interesting paper indeed. I am happy to say that crery time I hare the pleasure of hearing Captain Selwyn, he almays gratifies mo with the able manner in which these subjects are treated by him. With regard to the question of fuel, I must make one little excuse for Gorernment. Gorcrument lare a very large number of ressels : the machinery is already made. Of course improrements are daily taking place, and Gorernment could not afford to alter all the engines at once. But the merchant, who is fitting out perhaps only one ressel, 
can take adrantage of erery improrement, without any other iuconrenience than simply paying for the new alterations in the machinery. Gorernment cannot do that, at least until the improvements hare been well rerified. At the sane time I quite agree with Captain Selwesn that Gorernment are much too slow in adopting improrcments. With regard to sail-power, I also ngree with Captain Selwyn. In steamers, particularly, the eail-porrer ought to be entirely sccondary and subordinato to steam, crecpt in special cases. But there ought always to be sufficient eail-power in case of any accident lappening to the machinery or to the serew, to cnable the ressel to draw off from a lce-shore, or to reach a port suited for repairing its damages. I also agree with Captain Selwyn that the eail-porer ought nerer to be such that we should hope to depend upon it when a ressel is being close-hauled or beating to windward; that ought to be better done by steam, except in cases where steam is only the auriliary potrer with a disabled machinery. Sail should only be made use of in a fair wind and off a lee-shore. With regard to the forms of ships, thero are threc particular Finds of warfare that a nation's rar ships ouglt to be fitted to carry on, viz., coast warfare on an ẹnemg's coast; occan warfare, and defensice coast warfare. Each of these kinds of warfare demand epecial qualitics adapted for that particular scrrice, independent of the general and important qualities which should be common to all ressels of war to cuable them to act together. For clefensire warfare I think with Captain Seling that small vessels with one or two rery heary guns and the smallest possible tonnage, with some littlo sail-potrer, are likely to be vers useful for defensire means which, with the torpedo and ram, and the great improrements that hare taken place in artillers, throw all the adrantages entirely on the side of defence against a sea attack, and render it perfectly impossiblo for our shores to be sucecssfully inraded. I think it is quite erident that the adrantages just alluded to, if we choose to make usc of them, such as these small ressels, and those resscls which should be expressly constructed for the means of defence of our consts and harbours, as rams, torpedoes, railronds along the const, which would render us perfectly safe from any kind of attack that could be made against us from the sea by the combination of any number of mations. Time rould fail me to enter into details as to the forms of ressels best suited for the purpose. I am of opinion with Captain Selwgn in the gencral principles he has laid down. The eame remark rill apply to the next head, the utilisation of separate forms of ressels for scparate purposes; these are according to $m y$ riers the three forms that $I$ hare becn alluding to, and the three purposes for which the demands of naral warfare requires these forms, should be best adapted. I also agree mith Captain Sclutn as to the cconomy of the personnel. It is unnecessary to go orer the subject ngain; therefore, I shall conclude by thanking Captain Sclwyn for the rers uscful and interesting paper that he has read. 